\title{
IAMJ
}

INTERNATIONAL

AYURVEDIC

MEDICAL JOURNAL

[d] 1

\section{AYURVEDIC MANAGEMENT OF CHRONIC PID ASSOCIATED WITH CERVICAL INTRAEPITHELIAL NEOPLASIA - A CASE REPORT}

\author{
Prajitha. P. K ${ }^{1}$, Gouri Shanker Prasad. T $^{2}$.
}

${ }^{1}$ MS(Ay), Specialist Medical Officer - Prasuti Streeroga

District Ayurveda Hospital, Kozhikode, Kerala, India

${ }^{2} \mathrm{MD}$ (Ay), Assistant Professor, Dept. of Kayachikitsa

V. P. S. V. Ayurveda College, Kottakkal, Malappuram, Kerala, India

Corresponding Author: pkprajitha4@gmail.com

https://doi.org/10.46607/iamj2509032021

(Published online: March 2021)

Open Access

(C) International Ayurvedic Medical Journal, India 2021

Article Received: 16/02/2021 - Peer Reviewed: 26/02/2021 - Accepted for Publication: 04/03/2021

D) Check for updates

\section{ABSTRACT}

Pelvic inflammatory disease (PID) is the inflammatory condition of uterus, and associated structures, which are often sexually transmitted. Human Papilloma Virus (HPV) infection is the most prevalent sexually transmitted infection as well as the most important risk factor for Cervical Intraepithelial Neoplasia (CIN) and Invasive Cervical Carcinoma (ICC). CIN are dysplastic changes taking a long period to progress into true cancer. Currently treatment is not recommended for CIN 1\&2 lesions as they are said to regress in some cases. According to Ayurvedic principles, Garbashaya Mukha Sopha, can be managed with Vranaropana-Ojovardhaka drugs. The symptomatic management with anti-inflammatory and immune-modulatory drugs along with Sthanika chikitsa, together gave promising results even in cytological level. A 43-year-old lady presented with thick yellowish discharge per vagina along with lower abdominal pain \& low back ache. On examination, hypertrophied and eroded cervix was noticed along with positive cervical motion tenderness. She was sent to Regional Cancer centre, Trivandrum for cytological evaluation, which revealed LSIL (Low grade Squamous Intraepithelial lesion) with Koilocytic atypia. She was managed with oral medication and Sthanika chikitsa and got relieved from symptoms which was consistent even 
after the follow up period. The cytology revealed negative for intraepithelial lesion or malignancy. Ayurvedic modalities proved to be effective in management of Chronic PID with CIN.

Keywords: Pelvic inflammatory disease, Human Papilloma Virus, Cervical Intraepithelial Neoplasia, Garbashaya mukha sopha, Sthanika chikitsa,

\section{INTRODUCTION}

Pelvic inflammatory disease comprises a spectrum of inflammatory disorders of the upper female genital tract, including any combination of endometritis, salpingitis, tubo-ovarian abscess and pelvic peritonitis ${ }^{1}$. In most cases these infections are sexually transmitted due to organisms like Nisseria gonorrhoeae, Chamydia trachomatis, Herpes simplex virus, HPV etc., which are usually ascending infection from the vagina or cervix. Chronic PID is usually a sequel of acute PID, due to inadequate management. As the diagnosis in PID is largely clinical, gynaecological examination is often mandatory. As per Centers for Disease Control \&Prevention, one or more of the following minimum clinical criteria present on pelvic examination-Cervical motion tenderness (CMT), uterine tenderness or adnexal tenderness satisfy the clinical diagnosis of PID. Even though PID has not been evaluated as a precursor of CA cervix, presence of HPV is the most important risk in CIN and CA cervix. Human Papilloma Virus (HPV) infection is the most prevalent sexually transmitted infection as well as the most important risk factor $(99.5 \%)$ for Cervical Intraepithelial Neoplasia (CIN) and Invasive Cervical Carcinoma (ICC). In the cervix, the ectocervix is lined by squamous epithelium and the endocervical canal by the columnar epithelium. The junction of the two epithelia is the squamocolumnar junction $(\mathrm{SCJ})^{2}$. The area between the original and the active SCJ is the transformation zone (TZ) which is susceptible to oncogenic factors including HPV, and hence is the site of CIN. In multiparous women, due to cervical injury, ectropion and chronic cervicitis, the columnar epithelium is continuously exposed to the vaginal acidity. The hallmark of a symptomatic HPV infection is to produce proliferation of the stratified squamous epithelium. CIN is characterized by the progression from cellular atypia to various grades of dysplasia (CIN 1, 2, 3\&
Carcinoma in situ) before progressing to invasive carcinoma. Immune response of the individual is also important in persistence of HPV infection as humoral neutralising antibodies have capacity to clear the virus. Coming to the management of CIN, it is broadly categorised as- preventive $\&$ definitive ${ }^{3}$. No definitive treatment, instead observation for 6-12 months is usually recommended for CIN $1 \& 2$ lesions, whereas local ablative methods \& excisional methods are suggested in CIN 3/CIS. Eradication of precursor lesion is mandatory as an effective approach to the prevention of cervical cancer. In the context of Yoniroga (Gynaecologic diseases), Acharya Susrutha has pointed improper sexual practice (particularly coital act in young girls) as the most important etiology of yoni rogas ${ }^{4}$. HPV infection is an Aganthu roga (extrinsic diseases) by origin, but later it vitiates the bodily Dosa and Dhatu and manifest to a Nija roga (intrinsic diseases). There is affliction of the Rasarakta-mamsa dhatu, along with Srotovaigunya (impairment in bodily channels), which pave way for development of Sopha (edema) at the Garbashaya mukha (cervix)-CIN. This is in turn the Poorvarupa avastha(prodromal stage) of forthcoming Vyadhi (disease)- cervical cancer. In the initial stage CIN can be considered as a Vrana beda and treatment of Vranasopha can be employed. Pariseka(douche) being one among them, washes away the excessive discharge and aids healing. Since the disease has involvement of Mamsa dhatu, Sastra kshara agni karma has a major role, where Pratisaraneeya kshara has site specific action. Sodhana and Ropana are the prime modalities in Vrana chikitsa, which makes them the treatment of choice in CIN as well. In addition, drugs which improve the Vyadhikshamatwa (immunity) checks the recurrence of the disease. 


\section{Case Report:}

A 43 year old female patient approached the OPD, Govt. Ayurveda College Hospital for Women and Children, Poojappura, Thiruvanathapuram, with complaints of thick yellow white discharge per vaginum, lower abdominal pain and low back ache which was present since 4 years, and she also developed dyspareunia since 4months. Her gynecologic examination was done on 11/07/2013 which revealed thick yellowish discharge $\mathrm{p} / \mathrm{v}$ with hypertrophied and eroded cervix along with positive cervical motion tenderness, and bilaterally tender fornices. She was sent to the Community Oncology Dept. of Regional Cancer Centre, Thiruvanathapuram, for Papsmear and Colposcopy examination. She was diagnosed with Low Grade Squamous Intraepithelial Lesion with Koilocytic atypia in Pap smear \& HPV infection with Cervical Intraepithelial Neoplasia in Colposcopy on $13 / 09 / 2013$. She got admitted in the Hospital and was advised to take Gugguluthikthakam kasaya, Guggulupanchapala churna and Triphala guggulu tablet internally. IPD treatment given where Snehapana (Oleation) with Guuguluthikthaka ghrita, followed by Abhyanga- Usma sweda (Oil applicationSudation) with Pinda tailam, Virechana (Purgation) with Avipathi churna and Matravasthi (Enema) with Madhuyashtyadi tailam. Followed by the Sodhana (purification) procedures she was posted for the Sthanika chikitsa (local treatment) which includedYoni kshalana (Vaginal douche) with Triphala kashaya for 7 days, Kshara karma (Alkaline drug usage) with Tankana kshara for 3 days. There after Intravaginal Uttaravasthi (Retained douche) with Mahathikthaka ghrita for 3days and Pichu dharana (Tampoon) with Mahathikthaka ghrita for 7 days was also employed. On discharge she was advised to take Indukantham ghritam, Kadhaleemadhusnuhi rasayanam for next 3 months, as well as Rasagandhi mezhuk capsule for next 40 days. After 3 months review, she had marked symptomatic relief and the Papsmear and Colposcopy examination was repeated on 27/01/2014. The results revealed a smear negative for intraepithelial lesion or malignancy and Colposcopy showed minimal HPV flat lesion. Patient continued her medicines for three more months and was under follow up. After 1 year she again underwent Pap smear and Colposcopy (15/1/2015), which showed smear negative for intraepithelial lesion or malignancy, which was a clear indication of persistence of the results.

Table 1: Personal history

\begin{tabular}{|l|l|}
\hline Diet & Mixed \\
\hline Bowel & Constipated \\
\hline Appetite & Poor \\
\hline Micturition & Recurrent UTI \\
\hline Sleep & Disturbed \\
\hline Allergy & Nil \\
\hline Addictions & Nil \\
\hline
\end{tabular}

Table 2: Menstrual History

\begin{tabular}{|l|l|}
\hline Menarche & 13 year \\
\hline Cycles & Regular \\
\hline LMP & $01 / 07 / 2013$ \\
\hline Interval & $21-25$ days \\
\hline Duration & 2 days \\
\hline Amount & Moderate \\
\hline Clots & Minimal \\
\hline Dysmenorrhea & Absent \\
\hline
\end{tabular}


Obstetric History: P2L2A1- FTNVD, LCB-20yrs

Table 3: Per speculum examination

\begin{tabular}{|c|c|c|c|}
\hline $\mathbf{P} / \mathbf{S}$ & Vagina & Discharge & Present \\
\hline \multirow[t]{7}{*}{$(11 / 7 / 2013)$} & & Colour & Yellowish, Thick \\
\hline & & Amount & +++ \\
\hline & & Vaginitis & Present \\
\hline & Cervix & Size & Hypertrophied \\
\hline & & Cervicitis & Present \\
\hline & & Erosion & +++ ,all around \\
\hline & & Ectropion & Present \\
\hline \multirow[t]{5}{*}{$\mathbf{P} / \mathbf{V}$} & Uterus & Size & Normal \\
\hline & & CMT & + \\
\hline & & Consistency & Normal \\
\hline & Adnexae & Fallopian tubes & Not palpable \\
\hline & Fornices & & Tender +++ \\
\hline
\end{tabular}

Table 4: Management

Medicine/Procedures

Gugguluthikthakam kasaya

Guggulupanchapala churna

Triphala guggulu

Valuka sweda

Snehapana with Gugguluthikthaka ghrita

Abhyanga Usma sweda with Pindatailam

Virechanam with Avipathi churna with hot water

Matravasthi with Madhuyashtyadi tailam

Vaginal douche with Triphala kashaya

Kshara application with Tankana kshara

Intravaginal Uttaravasthi with Mahathikthaka ghrita

Pichu dharana with Mahathikthaka ghrita

\begin{tabular}{|l|l|}
\hline Dose & Duration \\
\hline $\begin{array}{l}96 \mathrm{ml} \text { bd } \\
1 \text { tsp bd with honey } \\
2 \mathrm{bd}\end{array}$ & 7 days \\
\hline- & \\
\hline $20 \mathrm{ml}-120 \mathrm{ml}$ & $\begin{array}{l}\text { 3days } \\
7 \text { days }\end{array}$ \\
- & 3days \\
$25 \mathrm{gm}$ & 1 day \\
$60 \mathrm{ml}$ & 7 days \\
\hline & 7days \\
1 pinch & 3days \\
& 3days \\
& 7days \\
\hline
\end{tabular}

Table 5: Follow up on 15/01/2014

\begin{tabular}{|c|c|c|c|}
\hline $\mathbf{P} / \mathbf{S}$ & Vagina & Discharge & Present \\
\hline \multirow[t]{7}{*}{$(15 / 01 / 2014)$} & & Colour & Egg white \\
\hline & & Amount & + \\
\hline & & Vaginitis & Absent \\
\hline & Cervix & Size & Hypertrophied \\
\hline & & Cervicitis & Absent \\
\hline & & Erosion & Absent \\
\hline & & Ectropion & Absent \\
\hline \multirow[t]{5}{*}{$\mathbf{P} / \mathbf{V}$} & Uterus & Size & Normal \\
\hline & & CMT & $-\mathrm{ve}$ \\
\hline & & Consistency & Normal \\
\hline & Adnexae & Fallopian tubes & Not palpable \\
\hline & Fornices & & Non tender \\
\hline
\end{tabular}


Table 6: Comparison of results

\begin{tabular}{|l|l|l|l|}
\hline Pap Smear & $\begin{array}{l}\text { Before treatment (13/9/2013) } \\
\text { Low Grade Squamous Intraepithelial } \\
\text { Lesion with Koilocytic atypia }\end{array}$ & $\begin{array}{l}\text { After treatment }(27 / 1 / 2014) \\
\text { Negative for intraepithelial } \\
\text { lesion or malignancy }\end{array}$ & $\begin{array}{l}\text { Final Review }(15 / 1 / 2015) \\
\text { Negative for intraepithelial } \\
\text { lesion or malignancy }\end{array}$ \\
\hline Colposcopy & $\begin{array}{l}\text { HPV infection with Cervical } \\
\text { Intraepithelial Neoplasia }\end{array}$ & Minimal HPV flat lesion & - \\
\hline
\end{tabular}

\section{Reports: (Regional Cancer Centre, Trivandrum)}

\section{DISCUSSION}

As per Ayurvedic classics, features of many Yonirogas have resemblance with the etio-pathogenesis of CIN. Multiple sexual partners, early marriage and childbearing are one of the major risk factors of HPV infection and thereby development of CIN. It begins as an aganthu roga which further results in tridosha $d u s h t i$, leads to development of sopha at the cervix. In addition, the usage of ahitha ahara leads to agni mandhya and ama formation, which hampers the dhatu pushti and finally effects the vyadhi kshamatwa or bala. In immune deficient patients, abnormal DNA prevails, and abnormal cells multiply to develop CIN lesions. This aids the further progression of the disease. The line of management aimed at correction of the tridosha dushti prevailing in the body along with local correction at the affected site-cervix. This included Sodhana, samana, sthanika chikitsa as the first-hand modality, further followed by Rasayana- ojovardhana drugs and practice of Sadvritta (code of conducts). Gugguluthikthaka yoga was chosen for internal administration as kashaya as well as ghrita for acha snehapana. Gugguluthikthaka is a polyherbal formulation with major ingredients being Guggulu and pancha thikta drugs which are known for their vata kapha hara, krimihara, shotagna as well as vrana ropana property. It's a proven drug in modulation of proinflammatory cytokines and enzymes in chronic inflammatory condition ${ }^{5}$. Guggulupanchapala churna mentioned in the context of Nadi vrana (sinuses) was another drug chosen. It being deepana pachana helps correct the amasanchaya in sookshma srotas and helps in removing the kleda, thereby cleanses the inflamed and dysplastic epithelium. Guggulupanchapala churna is rich in antioxidants ${ }^{6}$ which also acts as a rasayana that aid the healing process. Sodhana procedures were employed aiming correction of the dislodged dosa, and thereby bringing an equilibrium and check the disease progression. Sthanika chikitsa is having special emphasise in garbashaya mukha vrana. Mamsa dushti occurs in CIN lesions and hence kshara agni karmas are having special role. Drugs which impart immunity and has vrana ropana property will have an upper hand in the management of this infection as the virus is believed to enter the basal layer of the squamous epithelium through microtrauma. Local procedures mainly included vaginal douche with Triphala kashaya which is proven for its antimicrobial, wound healing and antioxidant activity ${ }^{7}$. Tankana kshara being katu rasa, is vrana avasadana - helps in healing erosion; because of its ruksha-ushna property is krimihara, and being Kapha Vishleshaka ${ }^{8}$, it checks discharge. Kshara karma helps in removing the unhealthy epithelium, checks discharge and promotes development of normal epithelial layer of cervix. In addition, intravaginal uttaravasthi and pichu dharana with Mahathikthaka ghrita ${ }^{9}$ aided the easy wound healing and antioxidant rich drugs of the formulation prevented recurrence. Indukantha ghrita $^{10}$ was advised in shaman matra during the follow up period, which was specially intended to improve the immune status of the patient. This ghrita helps in srotosodhana thereby preventing recurrence of the cervical lesion and is moreover rich in immune-modulatory and anti-inflammatory activity. Rasagandhi mezhuk ${ }^{11}$ is a herbo-mineral siddha preparation with particular emphasis in arbuda treatment. The ingredients being thikta katu rasa pradhana helps check excess kleda, clears the srotorodha as well as immune - modulatory action prevents recurrence of the disease. 
Kadhaleemadhusnuhi Rasayana mentioned in Lehya prakarana of Sahasrayoga ${ }^{12}$ is typically krimighna, sophahara, as well as rasayana, prevent the recurrence of the disease. These internal and local treatment measures ensured total relief in symptoms and moreover the cytological study brought negative result for intraepithelial lesion or malignancy.

\section{CONCLUSION}

PID is often a persisting condition in most of the women, often due to inappropriate or timely management. In turn $\mathrm{CIN}$ are dysplastic changes taking a long period to progress into true (invasive) cancer which point towards the continuum as well as the prognosis of ICC. Hence both needs to be addressed at a very early stage itself. Ayurvedic modalities with highlight to Sthanika chikitsa plays a pivotal role in management of such chronic gynecologic conditions. Both internal and external medication have facilitated the re-epithelisation of cervix to normal, as well prevented the recurrence.

\section{Acknowledgments}

We thank Dr. Asha Sreedar, Professor \& HOD, Department of Prasuti- Streeroga, Govt. Ayurveda College hospital for Women \& Children, Thiruvananthapuram for the scientific guidance and assistance in completion of this work.

\section{REFERENCES}

1. STD Treatment Guidelines. Centres for Disease Control \&Prevention 2015; Page no 728. (Last accessed on 2021 Feb 10). Available from: www.cdc.gov.std.pid

2. Sheila Balakrishnan. Textbook of Gynaecology. $2^{\text {nd }} e d$. Hyderabad: Paras Medical Publisher; 2016.p. 227.

3. D C Dutta. Textbook of gynaecology. $5^{\text {th }}$ ed. Kolkata: New Central Book Agency (P) Ltd; 2008.p. 315-317.

4. Kaviraj Kunjalal Bhishagratna. Susrutha Samhitha Vol 3(Uttarasthana). $3^{\text {rd }}$ ed. Varanasi. Chowkamba Sanskrit Series Office 2003.p. 315

5. Mohind C. Mohan, Anu P. Abhimannue, B. Prakash Kumar, Modulation of Proinflammatory cytokines \& enzymes by polyherbal formulation Gugguluthiktaka ghrita. J Ayurveda Integer Med. 2019 Jan 10; S09759476(18)30067-6. (Last accessed on 2021 Feb 08).
Available

from:

http://www.ncbi.nlm.nih.gov/pubmed/30638916

6. Sruthi C.V. and Sindhu A. A preliminary study on the phytochemicals and antioxidant potential of Guggulupanchapala Choorna used in the management of Fistula-in-ano. Int. J. Res. Ayurveda Pharm.2013; 4(4):519-521. (Last accessed on 2021 Feb 05). Available from: http://dx.doi.org/10.7897/22774343.04412

7. Muthusamy Senthil Kumar, Shanmugam Kirubanandan, Ramasamy Sripriya, Triphala promotes healing of infected full-thickness dermal wound. J Surg Res. 2008 Jan; 144(1):94-101. (Last accessed on 2021 Feb 11). Available from: http://www.ncbi.nlm.nih.gov/pubmed/17662304

8. Dr. Ravindra Angadi. Rasatarangini(Ayurveda Pharmaceutics \& Indian Alchemy). $1^{\text {st }}$ ed. Varanasi; Chaukhambha Surbharati Prakasan; 2015.p.217

9. Srikantha Murthy K R. Vagbhata's Ashtanga Hridaya. Vol-2 (Chikitsa Sthana). Chaukhambha Krishnadas academy.p.473

10. K.V. Krishnan Vaidyan, S. Gopala Pillai. Sahasrayogam. $32^{\text {nd }}$ ed. Mullakkal; Vidyarambham Publishers; October 2013.p.322.

11. Formulary of Siddha medicines. $6^{\text {th }}$ ed. Chennai; IMCOPS Publishers; 2012.p.168

12. K.V. Krishnan Vaidyan, S. Gopala Pillai. Sahasrayogam. $32^{\text {nd }}$ ed. Mullakkal; Vidyarambham Publishers; October 2013.p.230.

\section{Source of Support: Nil \\ Conflict of Interest: None Declared}

How to cite this URL: Prajitha. P. K., Gouri Shanker Prasad. T: Ayurvedic Management Of Chronic Pid Associated With Cervical Intraepithelial Neoplasia - A Case Re-port. International Ayurvedic Medical Journal \{online\} 2021 \{cited March, 2021\} Available from: http://www.iamj.in/posts/images/upload/668_673.pdf 